\title{
The gut microbiota profile of adults with kidney disease: A systematic review of the literature
}

Jordan Stanford ( $\sim$ js096@uowmail.edu.au )

University of Wollongong Faculty of Science Medicine and Health https://orcid.org/0000-0003-35418960

\section{Karen Charlton}

University of Wollongong Faculty of Science Medicine and Health

\section{Anita Stefoska-Needham}

University of Wollongong Faculty of Science Medicine and Health

\section{Rukayat Ibrahim}

University of Surrey Faculty of Health and Medical Sciences

\section{Kelly Lambert}

University of Wollongong Faculty of Science Medicine and Health

\section{Research article}

Keywords: Gut microbiota, chronic kidney disease, kidney stones, diet, systematic review, DNA sequencing Posted Date: November 4th, 2019

DOI: https://doi.org/10.21203/rs.2.10470/v2

License: (c) (i) This work is licensed under a Creative Commons Attribution 4.0 International License. Read Full License

Version of Record: A version of this preprint was published at BMC Nephrology on June 5th, 2020. See the published version at https://doi.org/10.1186/s12882-020-01805-w. 
The authors have withdrawn this preprint from Research Square 